\title{
Ewa Widz* \\ WAHANIA INDEKSÓW GIEŁDOWYCH A WAHANIA KONIUNKTURY GOSPODARCZEJ W POLSCE
}

\begin{abstract}
Streszczenie. Celem artykułu jest analiza zależności korelacyjnych między stopami zwrotu głównych indeksów giełdowych Giełdy Papierów Wartościowych w Warszawie a koniunkturą gospodarczą w Polsce mierzoną tempem wzrostu Produktu Krajowego Brutto oraz odpowiedź na pytanie, czy zmiany indeksów na rynku giełdowym wyprzedzają (a jeśli tak, to o ile) zmiany PKB. Analiza objęła lata 2003-2014. Podstawę badań stanowiły kwartalne wskaźniki dynamiki zmian indeksów giełdowych i PKB. Badania wykazały, że korelacja między dynamiką zmian głównych indeksów giełdowych GPW i dynamiką zmian PKB w Polsce jest dodatnia, ale umiarkowana. Zmiany indeksów wyprzedzają zmiany PKB, ale w przypadku dużych zmian PKB silniejsza korelacja występowała $\mathrm{z}$ równoczesnymi zmianami indeksów. Porównując otrzymane wyniki z wynikami wcześniej prowadzonych badań, można również wyciągnąć wniosek, że badane zależności na rynku polskim stopniowo słabną.
\end{abstract}

Słowa kluczowe: koniunktura giełdowa, indeksy Giełdy Papierów Wartościowych w Warszawie, dynamika Produktu Krajowego Brutto Polski.

JEL: G1, O4

\section{WPROWADZENIE}

Zależności między koniunkturą giełdową a koniunkturą gospodarczą są przedmiotem licznych badań (Filer, Hanousek, Campos 1999: 1-22, Levine, Loayza, Beck 2000: 31-77, Beck, Levine 2004: 423-442, Jin, Boubakari 2010: 14-20). O ile wątpliwości nie budzi to, iż takie zależności istnieją i są statystycznie istotne, to wciąż nie ma jednoznacznej odpowiedzi, jaki jest ich charakter i kierunek. Rozważania teoretyczne pozwalają na stwierdzenie, że zależności te są dwukierunkowe. Koniunktura giełdowa jest bez wątpienia czynnikiem determinującym wzrost gospodarczy. Potwierdzają to realizowane przez giełdę funkcje mobilizowania oszczędności podmiotów posiadających nadwyżki finansowe, alokacji kapitału i finansowania zróżnicowanych projektów inwestycyjnych. Dzięki prawidłowej realizacji tych funkcji poprzez dobrze rozwinięty rynek giełdowy do gospodarki trafiają zasoby kapitału, który może

*Uniwersytet Marii Curie-Skłodowskiej w Lublinie, Wydział Ekonomiczny, Instytut Ekonomii i Finansów, Zakład Rynków Finansowych, ewa.widz@umcs.lublin.pl 
być efektywnie wykorzystany. Z kolei wpływ sytuacji gospodarczej na koniunkturę giełdową można uzasadnić większym zainteresowaniem wszelkiego rodzaju produktami i usługami finansowymi w warunkach dobrej koniunktury gospodarczej. Oddziaływanie gospodarki na rynek giełdowy widać bezpośrednio w reakcjach inwestorów na publikowane dane makroekonomiczne i prowadzoną przez państwo politykę makroekonomiczną.

Zależności między rozwojem rynku giełdowego a wzrostem gospodarczym mają zatem charakter sprzężenia zwrotnego, jednakże większość badań empirycznych koncentruje się na oddziaływaniu systemu finansowego, w tym rynku kapitałowego, na wzrost gospodarczy. Badania te potwierdzają, że giełda wywiera istotną rolę w stymulowaniu wzrostu gospodarczego.

W analizie zależności badacze wykorzystują różne parametry charakteryzujące koniunkturę giełdową i koniunkturę gospodarczą. Najczęściej analizowanymi miernikami koniunktury giełdowej są: kapitalizacja spółek, głównie krajowych, relacja kapitalizacji do wielkości PKB, wielkość obrotów, ich relacja do kapitalizacji (wskaźnik płynności), liczba notowanych spółek czy liczba debiutów, a także zmiany poziomu indeksów giełdowych. Natomiast głównymi miernikami koniunktury gospodarczej są: PKB, PKB per capita, tempo wzrostu $\mathrm{PKB}$, poziom inwestycji, relacja inwestycji do PKB, tempo wzrostu inwestycji i stopa bezrobocia. Oczywiście stosowanie poszczególnych mierników jest obciążone różnymi wadami. Zwykle wskaźniki makroekonomiczne i giełdowe wyznacza się w odmienny sposób, co utrudnia przeprowadzanie badań. Wskaźniki makroekonomiczne prezentowane są najczęściej kwartalnie w odniesieniu do analogicznego kwartału roku poprzedniego. Z kolei wskaźniki rynku giełdowego prezentowane są codziennie w sposób ciągły, w porównaniu do ich poziomów z dnia poprzedniego. Porównanie zmian wskaźników wymaga natomiast zastosowania identycznych miar.

Celem artykułu jest analiza zależności korelacyjnych między stopami zwrotu głównych indeksów giełdowych Giełdy Papierów Wartościowych w Warszawie a koniunkturą gospodarczą w Polsce mierzoną tempem wzrostu Produktu Krajowego Brutto, a także odpowiedź na pytanie, czy zmiany indeksów na rynku giełdowym wyprzedzają (a jeśli tak, to o ile) zmiany PKB. W pracy postawiona została hipoteza badawcza, iż zmiany indeksów giełdowych wyprzedzają i tym samym prognozują zmiany PKB, a w szczególności silne zdolności prognostyczne indeksów dotyczą dużych, ponad 3-procentowych zmian PKB.

Analiza objęła lata 2003-2014. Podstawę badań stanowiły kwartalne wskaźniki dynamiki zmian indeksów giełdowych i PKB, wyrażające zmianę rok do roku, tj. na koniec danego kwartału w porównaniu z końcem analogicznego kwartału roku poprzedniego. Tym samym w analizie uwzględniono 48 wskaźników kwartalnych dla każdego badanego parametru. 


\section{GIELDA JAKO BAROMETR KONIUNKTURY - PRZEGLĄD BADAŃ EMPIRYCZNYCH}

W literaturze przedmiotu często wskazuje się, iż rynek giełdowy jest barometrem koniunktury. Powszechnie uznaje się, że zmiany koniunktury giełdowej sygnalizują z wyprzedzeniem zmiany koniunktury gospodarczej, jeśli gospodarka jest odpowiednio reprezentowana na giełdzie. Jest to związane z tym, iż zmiany cen akcji i wartości indeksów giełdowych są wynikiem decyzji inwestorów giełdowych, którzy zgodnie ze swoimi przewidywaniami dotyczącymi przyszłości wyznaczają najbardziej efektywne kierunki inwestycji. Przekonania inwestorów o nadchodzącej poprawie sytuacji gospodarczej z jednej strony wpływają pozytywnie na poziom indeksów giełdowych, a z drugiej zwiększają inwestycje finansowe, co przekłada się na wzrost inwestycji realnych. Z kolei negatywna ocena przyszłej sytuacji gospodarczej powoduje spadek poziomu indeksów i oddziałuje negatywnie także na inwestycje realne. Stąd wniosek, iż wartości indeksów giełdowych powinny zachowywać się w sposób wyprzedzający w stosunku do koniunktury gospodarczej. Mechanizm taki powinien występować przy założeniu, że skład spółek giełdowych jest reprezentatywny dla całej gospodarki, inwestycje finansowe na giełdach papierów wartościowych mają wpływ na inwestycje rzeczowe, a decyzje inwestorów giełdowych są racjonalne, co oznacza, że wybierają oni perspektywiczne kierunki inwestowania (Wyżnikiewicz 2007: 21-23). Dodatkowo płynność rynku giełdowego powoduje, że inwestycje nie muszą mieć długoterminowego charakteru, a zaangażowanie inwestorów giełdowych może zmieniać się wraz ze zmianą przewidywań dotyczących przyszłych cen akcji.

$\mathrm{Na}$ tej podstawie można postawić hipotezę, że zmiany indeksów giełdowych są wyprzedzające w stosunku do zmian PKB. Wyniki badań empirycznych nie są jednak w tym względzie takie jednoznaczne.

Badania Famy (1990: 1089-1108) i Schwerta (1990: 1237-1257) z 1990 r. wykazały, że znaczną część zmienności cen akcji można wyjaśnić przyszłymi wynikami gospodarczymi, zaś między stopami zwrotu z akcji a stopami wzrostu gospodarczego w przyszłości istnieje silna korelacja. Jej występowanie potwierdzili także swoimi badaniami Demirguc-Kunt i Levine (1996: 223-240) oraz Filer, Hanousek i Campos (na podstawie danych z 70 państw) (1999: 19-21). W 2001 r. Hassapis i Kalyvitis opracowali model opisujący zależność pomiędzy zmianami stóp zwrotu z akcji a stopami wzrostu gospodarczego w przyszłości, który następnie przetestowali dla krajów G-7, choć dla Włoch nie udało się stwierdzić takiej zależności (2001: 3-9, 2002: 543-575).

W literaturze nie brak jest także skrajnie odmiennych wyników badań. Kassimatis i Spyrou w 2001 r. na podstawie badań kilku gospodarek wschodzących stwierdzili, że rynek akcji albo ma wpływ negatywny, albo nie ma wpływu na tempo wzrostu gospodarczego. Biswanger w 2003 r. wykazał, że silna relacja pomiędzy 
rynkiem akcji a przyszłą aktywnością gospodarczą w USA istniała, ale zanikła na początku lat 80. Podobne zjawisko zaobserwował w odniesieniu do gospodarki Japonii. Sawhney, Anoruo i Feridun w 2005 r. swoimi badaniami długoterminowych zależności pomiędzy cenami akcji i PKB udowodnili (przy wykorzystaniu testów przyczynowości Grangera), że w USA w badanym przez nich okresie wzrost gospodarczy był przyczyną zmian cen akcji, a nie na odwrót. W Kanadzie natomiast stwierdzili związki dwukierunkowe (Gajdka, Brzeszczyński, Schabek 2009: 3-9).

Polscy naukowcy również nie są zgodni co do charakteru zależności między zmianami cen akcji a zmianami koniunktury gospodarczej. Według Fundowicza w początkowym okresie funkcjonowania GPW w Warszawie, tj. do grudnia $1995 \mathrm{r}$., nie istniała zależność między wahaniami na giełdzie i w polskiej gospodarce. Sytuacja zmieniła się po 1996 r., kiedy współczynniki korelacji tempa zmian WIG oraz PKB istotnie wzrosły (do 0,73 za okres 1996 - I kwartał 2003), przy czym wykryto jednocześnie, iż zachowanie WIG w analizowanym okresie wyprzedzało o kwartał odbicia koniunktury od dna, a w stosunku do szczytów cykli koniunkturalnych WIG był wskaźnikiem równoczesnym lub opóźnionym (Fundowicz 2003: 147-151).

Kolejne badania prowadzone w ramach Instytutu Badań nad Gospodarką Rynkową potwierdziły, że indeks WIG odzwierciedla zmiany koniunktury gospodarczej, a przesunięcia czasowe zmian indeksu giełdowego mogą mieć zarówno charakter wyprzedzający, jak i opóźniony w stosunku do zmian PKB, w zależności od analizowanej fazy koniunktury. Współczynnik korelacji między badanymi wielkościami w latach 1996-2005 wyniósł 0,72. Na podstawie analizy danych kwartalnych stwierdzono, myląc się w 10 przypadkach na 100, że indeks WIG był przyczyną zmian PKB w Polsce w sensie Grangera (Kasprzak-Czelej 2012: 159).

Według Wyżnikiewicza (2007: 29) zmiany koniunktury giełdowej w Polsce na ogół z wyprzedzeniem sygnalizują zmiany krajowej koniunktury makroekonomicznej. Najściślejszy związek między zmianami indeksów giełdowych a zmianami PKB wśród badanych przez Wyżnikiewicza krajów zachodził dla gospodarki USA (przy poziomie istotności poniżej 1\%), nieco słabszy dla gospodarki brytyjskiej (poziom istotności poniżej 5\%), a najsłabszy dla gospodarki polskiej (poziom istotności poniżej 10\%) (Wyżnikiewicz 2007: 25).

Gajdka, Brzeszczyński i Schabek wykazali, iż między zmianami indeksu WIG i zmianami PKB w latach 1996-2008 występowała dodatnia korelacja na poziomie 0,66, a w okresie do początku kryzysu finansowego w III kwartale 2007 r. nawet wyższa $-0,73$. Nie stwierdzili jednak przyczynowości dla danych miesięcznych (od kwietnia 1992 r. do września 2008 r.). Natomiast dla danych kwartalnych (I kwartał 1995 r. - II kwartał 2008 r.) wykazali przyczynowość w sensie Grangera w obydwu kierunkach, ale silniej w kierunku od zmian PKB do zmian WIG. Na analizowane 52 kwartały zmiana PKB poprawnie sygnalizowała zmianę poziomu WIG w 67,31\% przypadków dla kwartalnej stopy zwrotu WIG liczonej rok do roku oraz w $61,54 \%$ przypadków dla kwartalnej stopy zwrotu WIG liczonej kwartał do kwartału (Gajdka, Brzeszczyński, Schabek 2009: 3-9). 
Z kolei badania Stąpały wykazały, że w latach 1998-2011 tempo zmian WIG wyprzedzało tempo zmian PKB średnio o 1,12 kwartału. Średnie wyprzedzenie dla szczytów wyniosło 1 kwartał, natomiast dla dna cyklu 1,75 kwartału. Korelacja dla rzędu opóźnień t-2 była bardzo istotna i wyniosła 0,64 . Zauważono również, porównując cykle na zegarze koniunktury, że od początku 1998 r. do II kwartału 2005 r. korelacja faz cyklu giełdowego i gospodarczego była bardzo wysoka. Sytuacja ta uległa zmianie po 2005 r., kiedy to siła powiązań znacznie spadła (Stąpała 2012: 371-392).

Według badań Gajdki i Pietraszewskiego opublikowanych w 2014 r., w początkowym okresie rozwoju rynku kapitałowego w regionie Europy Środkowo-Wschodniej związek pomiędzy stopą zwrotu z akcji a stopą wzrostu PKB miał charakter korelacji pozytywnej. Badacze wysnuli hipotezę, że w krajach, w których rynek kapitałowy znajduje się w fazie początkowego rozwoju, związek pomiędzy gospodarką realną a rynkiem kapitałowym jest pozytywny i silniejszy niż w państwach o znacznie silniej rozwiniętych rynkach kapitałowych, w których w długim okresie dochodzi do negatywnej korelacji pomiędzy wynikami uzyskiwanymi w realnej gospodarce a wynikami na rynku kapitałowym (Gajdka, Pietraszewski 2014: 399-408).

\section{BADANIE WYPRZEDZAJĄCYCH WLASNOŚCI GLÓWNYCH INDEKSÓW GPW W WARSZAWIE}

Badanie zależności korelacyjnych pomiędzy stopami zwrotu głównych indeksów GPW w Warszawie a stopami wzrostu PKB w Polsce zostało oparte o analizę współczynników korelacji Pearsona dla różnych rzędów opóźnień czasowych szeregów danych. Dla najsilniejszych powiązań oszacowano parametry strukturalne funkcji regresji metodą najmniejszych kwadratów, a także wyznaczono standardowe błędy oceny wartości zmiennej objaśnianej (stopy wzrostu PKB).

$\mathrm{Na}$ wykresach 1 i 2 przedstawiona została dynamika zmian PKB i głównych indeksów GPW: WIG, WIG20, mWIG40 i sWIG80 rok do roku dla poszczególnych kwartałów w latach 2003-2014. W analizowanym okresie nie odnotowano w naszym kraju ujemnej dynamiki PKB w ujęciu rocznym, podczas gdy roczne stopy zwrotu indeksów giełdowych były ujemne i sięgały nawet $60 \%$ in minus. Największe spadki poziomu indeksów miały miejsce w IV kwartale 2008 r., kiedy zmiany indeksów giełdowych r/r wyniosły: dla WIG $-51,07 \%$, dla WIG20 $-48,21 \%$, dla mWIG40 - 62,48\%, a dla sWIG80 - 56,95\%. Z kolei największe wzrosty indeksów WIG i WIG20 zanotowano w I kwartale 2010 r. (odpowiednio 76,59\% i 65,07\%), indeksu mWIG40 w II kwartale 2007 r. (wzrost o 113,59\%), a indeksu sWIG80 w I kwartale 2004 r. (wzrost o 191,03\%). Wysokiej dynamice wzrostu indeksów giełdowych towarzyszyła wysoka dynamika wzrostu PKB, 
przy czym największe wzrosty PKB r/r zanotowano w I kwartale 2004 r. - 6,98\% i I kwartale 2007 r. $-7,71 \%$.

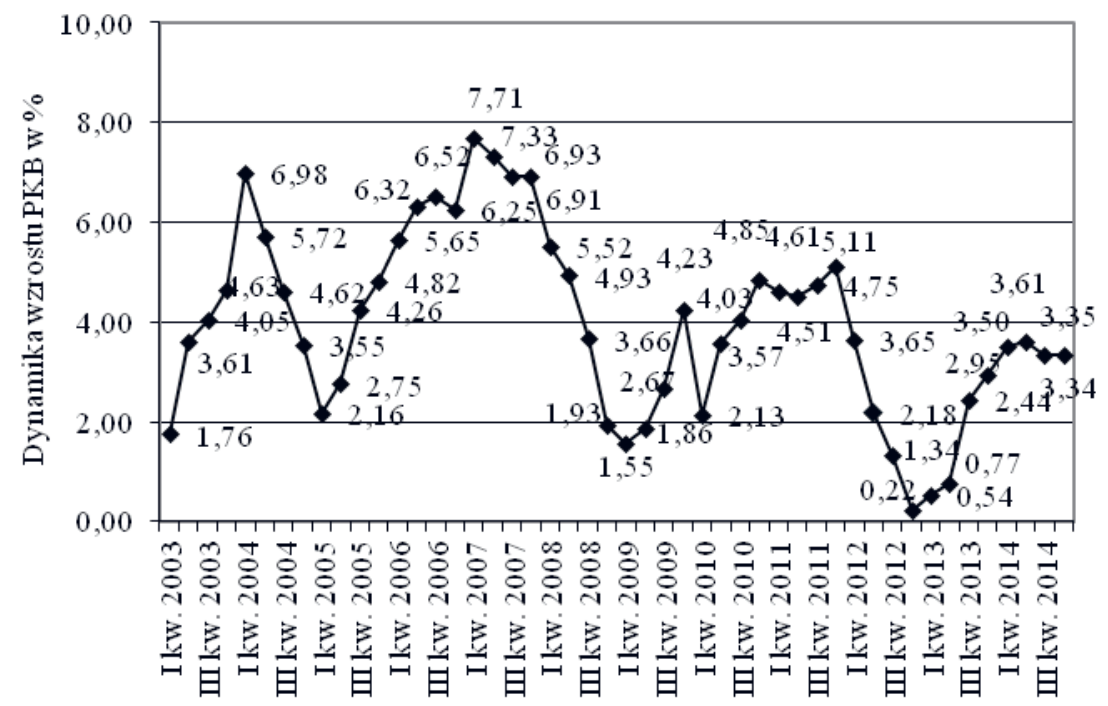

Wykres 1. Dynamika wzrostu PKB Polski r/r w latach 2003-2014 - wskaźniki kwartalne Źródło: opracowanie własne.

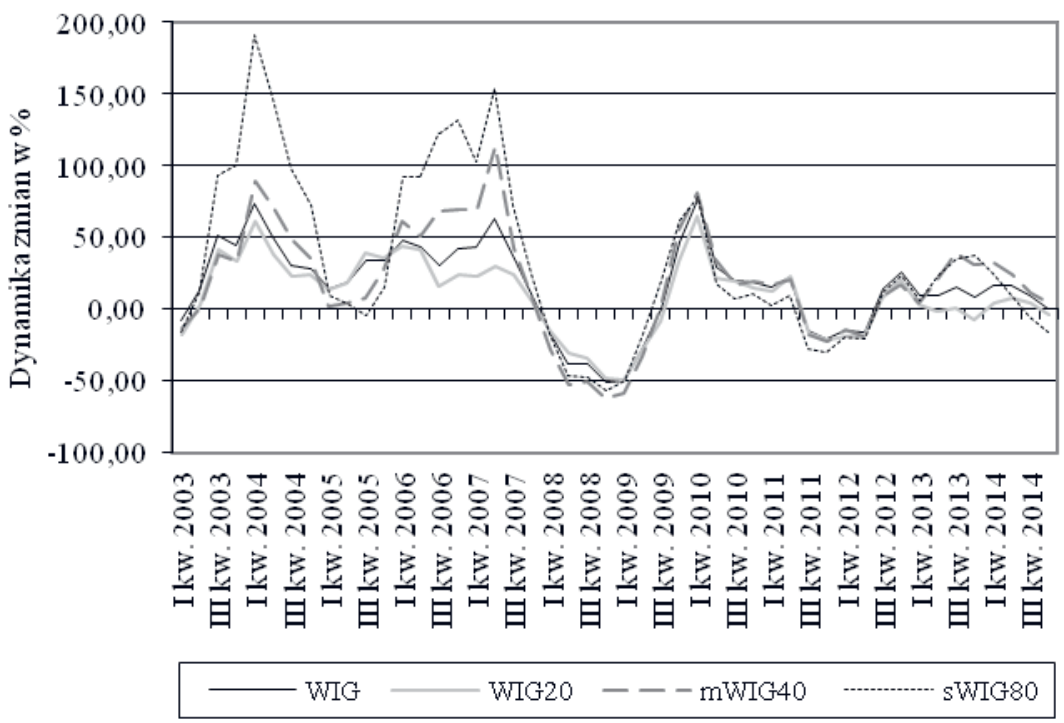

Wykres 2. Dynamika zmian indeksów WIG, WIG20, mWIG40 i sWIG80 r/r w latach 2003-2014 - wskaźniki kwartalne

Źródło: opracowanie własne. 
Pomimo iż wahania poziomu indeksów giełdowych i stóp zwrotu indeksów były o wiele większe niż wahania tempa wzrostu gospodarczego, występowała - wyraźnie widoczna na obu wykresach - charakterystyczna cykliczność tych wahań, przy czym spadkom stóp zwrotu indeksów giełdowych towarzyszyło niższe tempo wzrostu PKB, a wzrostom stóp zwrotu indeksów - wyższe tempo wzrostu PKB. Największą dynamiką zmian r/r w badanym okresie cechował się indeks sWIG80, zwłaszcza w okresie wzrostów (IV kwartał 2003 r. - II kwartał 2004 r. i III kwartał 2006 r. - II kwartał 2007 r., kiedy dynamika wzrostu r/r przekraczała $100 \%$ ).

Ze względu na to, że poszczególne indeksy obejmują spółki różnej wielkości (o różnej kapitalizacji i płynności obrotu) i nie są w pełni reprezentatywne dla całej gospodarki, zbadana została korelacja między stopami zwrotu głównych indeksów giełdowych. Pozwoliło to określić, czy indeksy zachowują się w podobny sposób, a zatem czy zasadne jest badanie zależności między tempem wzrostu PKB i stopami zwrotu poszczególnych indeksów. W okresie badawczym 2003-2014 stopy zwrotu indeksu WIG okazały się najsilniej skorelowane ze stopami zwrotu indeksu WIG20, a najsłabiej ze stopami zwrotu indeksu sWIG80 (tabela 1). Oznacza to, że zachowanie małych spółek reprezentowanych przez indeks sWIG80 odbiega od zachowania ogółu spółek notowanych na Głównym Rynku GPW - uczestników indeksu WIG, a badanie własności prognozowania przyszłych zmian koniunktury giełdowej przez oba indeksy może dać istotnie odmienne wyniki.

Tabela 1

Macierz korelacji stóp zwrotu głównych indeksów giełdowych GPW w Warszawie w latach 2003-2014

\begin{tabular}{|c|c|c|c|c|}
\hline $\begin{array}{c}\text { Dzienne stopy } \\
\text { zwrotu indeksów }\end{array}$ & WIG & WIG20 & mWIG40 & sWIG80 \\
\hline WIG & 1 & 0,9812 & 0,8366 & 0,7492 \\
\hline WIG20 & 0,9812 & 1 & 0,7407 & 0,6649 \\
\hline mWIG40 & 0,8366 & 0,7407 & 1 & 0,8092 \\
\hline sWIG80 & 0,7492 & 0,6649 & 0,8092 & 1 \\
\hline
\end{tabular}

Źródło: obliczenia własne.

W tabeli 2 przedstawione zostały wielkości współczynników korelacji rocznych stóp zwrotu głównych indeksów giełdowych i rocznego tempa wzrostu PKB Polski w latach 2003-2014 na podstawie wskaźników kwartalnych. Zależności korelacyjne zbadano dla różnego poziomu przesunięć czasowych $-\mathrm{w}$ wariantach, gdy zmiany indeksów są równoczesne ze zmianami PKB $(\mathrm{t}=0)$, gdy wyprzedzają zmiany PKB o 1, 2 lub 3 kwartały (odpowiednio t-1, t-2 i t-3) oraz gdy zmiany PKB wyprzedzają zmiany indeksów $(\mathrm{t}+1)$. 
Korelacja rocznych stóp zwrotu głównych indeksów giełdowych i rocznego tempa wzrostu PKB Polski w latach 2003-2014 - na podstawie wskaźników kwartalnych

\begin{tabular}{|c|c|c|c|c|c|}
\hline Korelacja & WIG & WIG20 & mWIG40 & sWIG80 & Rząd opóźnień \\
\hline PKB & 0,2344 & 0,2153 & 0,3160 & $0,4218^{*}$ & $\mathrm{t}+1$ \\
\hline PKB & $0,4212^{*}$ & $0,3968^{*}$ & $0,4902^{*}$ & $0,5625^{*}$ & $\mathrm{t}=0$ \\
\hline PKB & $0,5170^{*}$ & $0,4889^{*}$ & $0,5460^{*}$ & $0,5903^{*}$ & $\mathrm{t}-1$ \\
\hline PKB & $0,5890^{*}$ & $0,5666^{*}$ & $0,5866^{*}$ & $0,5753^{*}$ & $\mathrm{t}-2$ \\
\hline PKB & $0,5592^{*}$ & $0,5534^{*}$ & $0,5182^{*}$ & $0,4694^{*}$ & $\mathrm{t}-3$ \\
\hline
\end{tabular}

* współczynniki korelacji statystycznie istotne na poziomie istotności $\alpha=0,01$ (na podstawie testu istotności $t$ ).

Źródło: obliczenia własne.

Najsilniejsza korelacja $(0,5903)$ wystąpiła w badanym okresie między tempem zmian PKB i tempem zmian sWIG80 ${ }_{\mathrm{t}-1}$. Oznacza to, że zmiany indeksu sWIG80 w latach 2003-2014 w 35\% wyjaśniały zmiany PKB w następnym kwartale (wykres 3). Nieco słabsza zależność (korelacja na poziomie 0,5890) łączyła zmiany PKB ze zmianami WIG występującymi dwa kwartały wcześniej (wykres 4). Porównując otrzymane wyniki z wynikami wcześniej prowadzonych badań, można również wyciągnąć wniosek, że zależność między tempem zmian PKB i tempem zmian indeksów giełdowych na polskim rynku stopniowo słabnie.

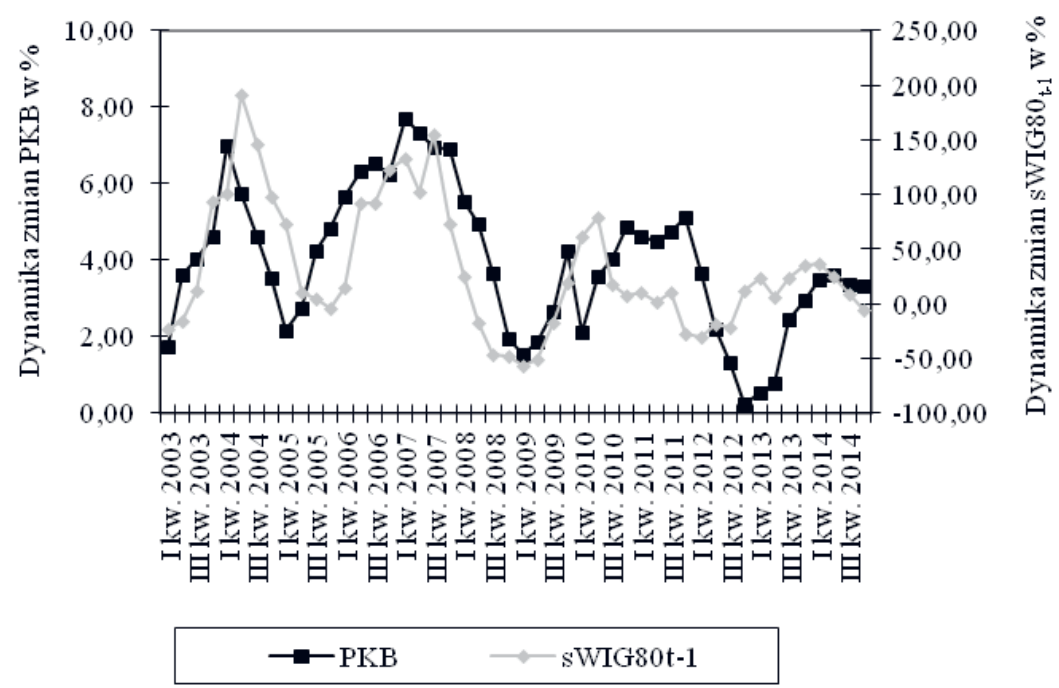

Wykres 3. Dynamika zmian PKB na tle zmian poziomu indeksu sWIG80 ${ }_{\mathrm{t}-1} \mathrm{w}$ latach 2003-2014 Źródło: opracowanie własne. 


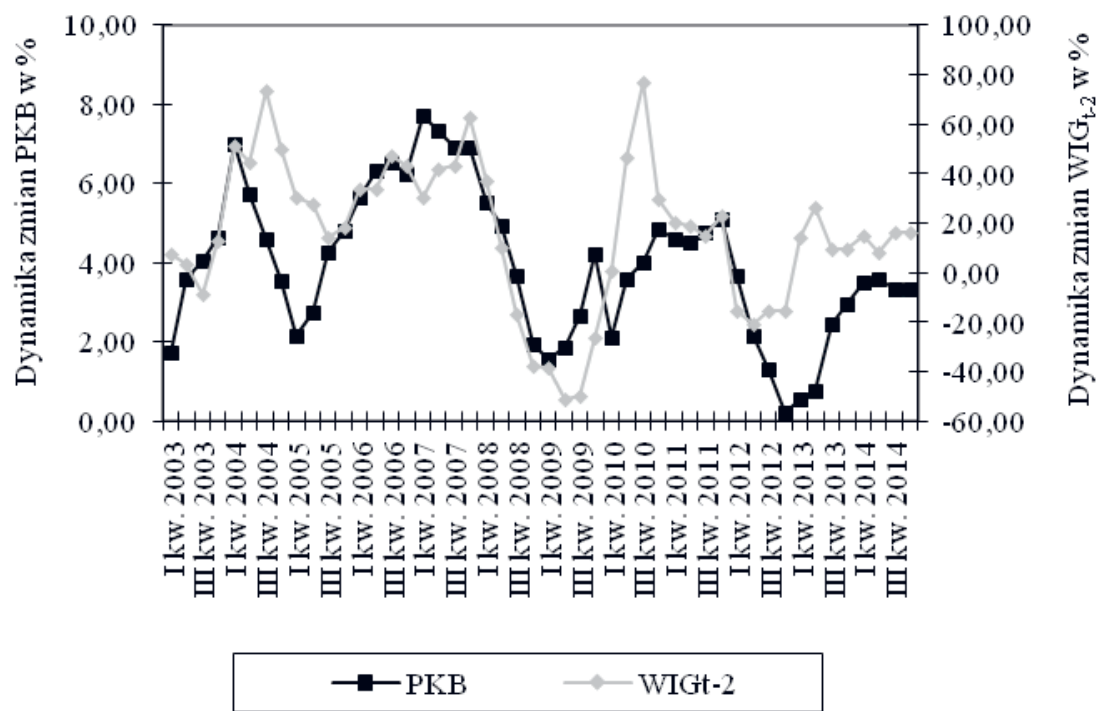

Wykres 4. Dynamika zmian PKB na tle zmian poziomu indeksu $\mathrm{WIG}_{\mathrm{t}-2}$ w latach 2003-2014 Źródło: opracowanie własne.

W celu ustalenia powiązań stóp zwrotu indeksu sWIG80 i tempa wzrostu PKB w kolejnym kwartale oraz stóp zwrotu indeksu WIG i tempa wzrostu PKB występującego dwa kwartały później oszacowane zostały parametry strukturalne funkcji regresji metodą najmniejszych kwadratów:

$\triangle P \hat{K} B=3,3671+0,0187 \Delta s W I G 80_{t-1}$

$\Delta P \hat{K} B=3,3739+0,0370 \Delta W I G_{t-2}$,

gdzie:

$\triangle P \hat{K} B$ - teoretyczne wartości zmiennej objaśnianej ( $\triangle P K B$ - stopy wzrostu $\mathrm{PKB})$ wynikające z oszacowania funkcji regresji,

$\Delta s W I G 80_{t-1}$ - stopa zwrotu indeksu sWIG80 w okresie t-1 (zmienna objaśniająca), $\Delta W I G_{t-2}$ - stopa zwrotu indeksu WIG w okresie t-2 (zmienna objaśniająca).

Współczynniki zbieżności (indeterminacji) dla obu badanych zależności wyniosły $65 \%$, co oznacza, że w takiej części zmiany PKB nie zostały wyjaśnione przez zmiany indeksów sWIG80 ${ }_{t-1}$ i WIG $_{t-2}$. Natomiast standardowe błędy szacunku zmiennej objaśnianej wyniosły odpowiednio 1,525 i 1,524. Na podstawie przeprowadzonych wyliczeń i badania istotności współczynnika regresji liniowej można stwierdzić, że oszacowane parametry funkcji regresji są nieistotne statystycznie (nie ma podstaw do odrzucenia hipotezy zerowej $H_{0}: \alpha_{1}=0$ na poziomie istotności 0,05 ). 
Prowadzi to do wniosku, że badane zależności nie mają jednak charakteru liniowego (co potwierdzają wykresy 5 i 6) i należy poszukiwać innych typów zależności.

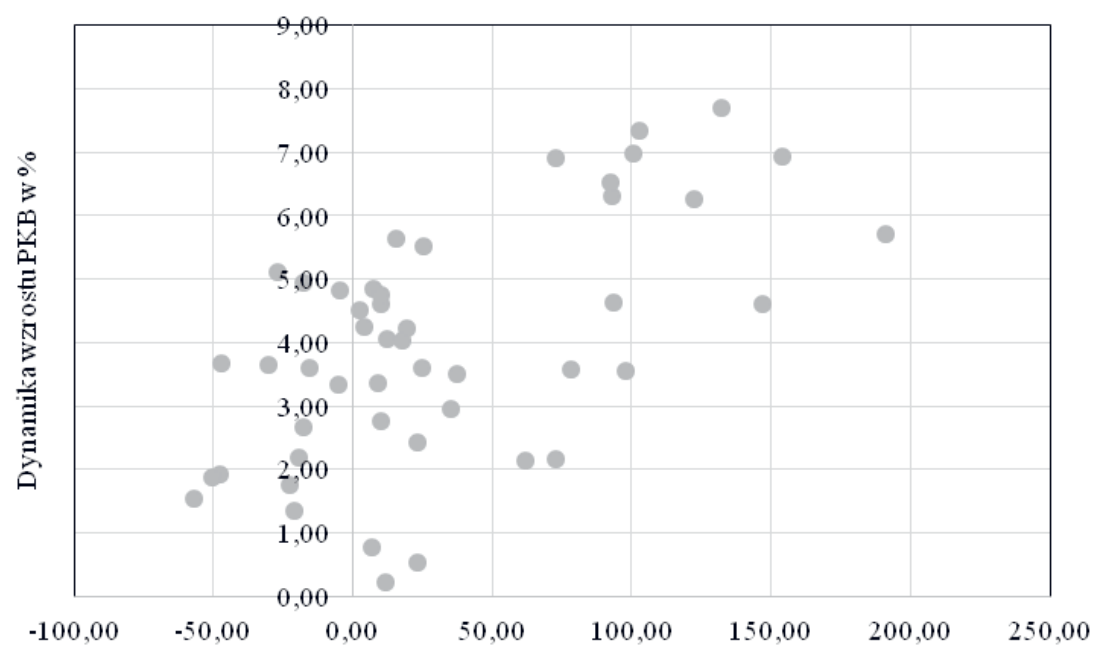

Dynamika zmian poziomusWIG80 $0_{t-1} \mathrm{~W} \%$

Wykres 5. Korelacja dynamiki zmian PKB z dynamiką zmian indeksu sWIG80 w latach 2003-2014

Źródło: opracowanie własne.

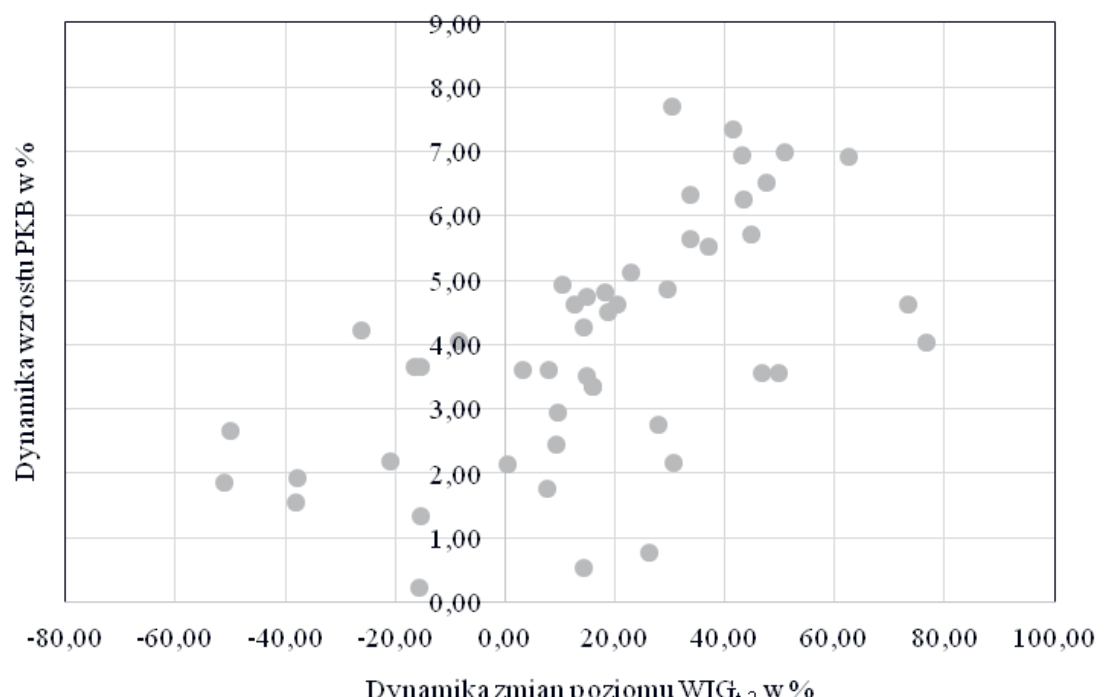

Wykres 6. Korelacja dynamiki zmian PKB z dynamiką zmian indeksu $\mathrm{WIG}_{\mathrm{t}-2}$ w latach 2003-2014 Źródło: opracowanie własne. 
Dodatkowych informacji dostarcza analiza zależności korelacyjnych przeprowadzona dla zmian PKB przekraczających 3\% (tabela 3). Pozwala ona uzyskać odpowiedź na pytanie, czy zmiany poziomu indeksów wyprzedzają w jednakowym stopniu wszystkie zmiany PKB (bez względu na ich wielkość) czy może tylko te największe. Badania wykazują, że korelacja między dynamiką zmian głównych indeksów giełdowych GPW i dynamiką dużych (ponad 3-procentowych) zmian PKB w Polsce jest dodatnia, ale umiarkowana. Największą wartość współczynnika korelacji zanotowano dla zależności zmian indeksu sWIG80 z równoczesnymi dużymi zmianami PKB $(0,6142)$. Nieco niższa korelacja wystąpiła między zmianami indeksu mWIG40 i jednoczesnymi dużymi zmianami PKB (korelacja na poziomie 0,5287). Oznacza to, że zmiany poziomu tych indeksów nie tyle wyprzedzają duże zmiany PKB, co im towarzyszą.

Tabela 3

Korelacja rocznych stóp zwrotu głównych indeksów giełdowych i dynamiki wzrostu PKB Polski powyżej 3\% w latach 2003-2014 - na podstawie wskaźników kwartalnych

\begin{tabular}{|c|c|c|c|c|c|}
\hline Korelacja & WIG & WIG20 & mWIG40 & sWIG80 & Rząd opóźnień \\
\hline PKB & 0,2258 & 0,1234 & 0,3653 & $0,4487^{*}$ & $\mathrm{t}+1$ \\
\hline PKB & 0,4258 & 0,3356 & $0,5287^{*}$ & $0,6142^{*}$ & $\mathrm{t}=0$ \\
\hline PKB & $0,4780^{*}$ & 0,4117 & $0,5139^{*}$ & $0,6007^{*}$ & $\mathrm{t}-1$ \\
\hline PKB & $0,4666^{*}$ & 0,4324 & $0,4666^{*}$ & $0,5249^{*}$ & $\mathrm{t}-2$ \\
\hline PKB & 0,3321 & 0,3519 & 0,2912 & 0,3268 & $\mathrm{t}-3$ \\
\hline
\end{tabular}

* współczynniki korelacji statystycznie istotne na poziomie istotności $\alpha=0,01$ (na podstawie testu istotności $t$ ).

Źródło: obliczenia własne.

\section{PODSUMOWANIE}

Tempo zmian PKB w Polsce jest powiązane z tempem zmian indeksów giełdowych na GPW w Warszawie w stopniu umiarkowanym, a zmiany indeksów ogólnie wyprzedzają zmiany PKB: o jeden kwartał w przypadku indeksu sWIG80 i dwa kwartały w przypadku indeksów WIG, WIG20 i mWIG40. Korelacja jest dodatnia, ale stopniowo słabnie, co potwierdza rezultaty badań prowadzonych wcześniej przez innych badaczy: Gajdkę, Pietraszewskiego, Brzeszczyńskiego, Schabka i Stąpałę. Analiza wykazuje ponadto, że indeksy mWIG40 i sWIG80 nie mają szczególnych własności wyprzedzających w stosunku do dużych zmian PKB, a jedynie współtowarzyszą tym zmianom. Z kolei siła powiązań stóp zwrotu indeksów WIG i WIG20 z ponad 3-procentowymi zmianami PKB była relatywnie 
słaba (dla wszystkich przesunięć czasowych wynosiła poniżej 0,5). Tym samym postawiona hipoteza o silnej korelacji wysokiego tempa wzrostu PKB i stóp zwrotu głównych indeksów giełdowych w okresach poprzedzających wzrost PKB została zweryfikowana negatywnie.

Badając zależności między rynkiem giełdowym a gospodarką trzeba pamiętać, że na wzrost gospodarczy wpływa wiele czynników, a koniunktura giełdowa jest tylko jednym z nich. Analizując z kolei sytuację giełdową na danym rynku trzeba odnotować, że zachowanie indeksów giełdowych jest wynikiem nie tylko czynników fundamentalnych, ale i tych o charakterze behawioralnym. Należy też uwzględnić wpływ zagranicznych czy międzynarodowych rynków finansowych, zwłaszcza w przypadku giełd z krótką historią lub niedojrzałych, gdzie stopień powiązań jest bardzo wysoki. Postępująca globalizacja powoduje bowiem, iż zachowania indeksów giełdowych na głównych rynkach upodobniają się do siebie (Widz 2010: 241-253).

W czasie ostatniego kryzysu finansowego Polska pozostawała jedynym krajem z dodatnią dynamiką zmian PKB w Unii Europejskiej. Mimo to spadki poziomu indeksów były tu nawet większe niż w UE. Z drugiej strony, bardziej rozwinięte kraje - pomimo występującej recesji - odbudowały pozycję rynku kapitałowego, a ich indeksy giełdowe są dziś na poziomie wyższym niż przed kryzysem (Niemcy, Wielka Brytania, USA). Wydaje się więc, że nie można porównywać powiązań naszego rynku giełdowego i gospodarki z sytuacją w krajach rozwiniętych i z występującymi tam związkami między rynkami giełdowymi a gospodarkami, chociaż $\mathrm{w}$ obu przypadkach następuje podobna tendencja osłabienia siły korelacyjnej między koniunkturą giełdową i koniunkturą gospodarczą.

\section{BIBLIOGRAFIA}

Adamopoulos A. (2010), Stock market and economic growth: an empirical analysis for Germany, "Business and Economic Journal", BEJ-1.

Beck T., Levine R. (2004), Stock markets, banks, and growth: Panel evidence, "Journal of Banking \& Finance", vol. 28.

Bukowski S. (2013), Rynki finansowe a wzrost gospodarczy w wybranych nowych krajach członkowskich Unii Europejskiej, „Zarządzanie i Finanse”, “Journal of Management and Finance", r. 11, nr 2, cz. 4, Sopot.

Demirguc-Kunt A., Levine R. (1996), Stock markets, corporate finance and economic growth, "World Bank Economic Review", vol. 10 (2).

Dębski W., Bujnowicz I. (2008), Model wspólzależności rozwoju systemu finansowego i wzrostu gospodarczego w Polsce, ,Studia i Prace Wydziału Nauk Ekonomicznych i Zarządzania”, nr 9, Wydawnictwo Naukowe Uniwersytetu Szczecińskiego, Szczecin.

Fama E. (1990), Stock returns, expected returns, and real activity, "Journal of Finance", vol. 45.

Filer R.K., Hanousek J., Campos N.F. (1999), Do Stock Markets Promote Economic Growth?, "CERGE-EI Working Paper Series", no. 151. 
Fundowicz J. (2003), Koniunktura giełdowa a koniunktura makroekonomiczna, [w:] K. Piech, S. Pangsy-Kania (red.) (2003), Diagnozowanie koniunktury gospodarczej w Polsce, Dom Wydawniczy Elipsa, Warszawa.

Fundowicz J., Łapiński K. (2009), Załamanie rynku kapitałowego 2008 roku a kryzys gospodarczy, [w:] J. Garczarczyk (red.) (2009), Rynek ustug finansowych a koniunktura gospodarcza, CeDeWu, Warszawa.

Fundowicz J., Wyżnikiewicz B. (2006), Fluktuacje koniunktury gospodarczej i giełdowej - perspektywa makroekonomiczna, [w:] M. Mocek (red.) (2006), Diagnozowanie i prognozowanie koniunktury gospodarczej w Polsce, Akademia Ekonomiczna w Poznaniu, Katedra Badań Marketingowych, Poznań.

Gajdka J., Brzeszczyński J., Schabek T. (2009), Koniunktura giełdowa a zmiany w realnej sferze gospodarki w Polsce, ,Przegląd Organizacji”, nr 7-8, www.oizet.p.lodz.pl/kncashflow/images/ mat/Gajdka_Jerzy.pdf (dostęp: 26.06.2015).

Gajdka J., Pietraszewski P. (2014), Wzrost gospodarczy a ceny akcji, „Zeszyty Naukowe Uniwersytetu Szczecińskiego", nr 804, Finanse, rynki finansowe, ubezpieczenia, nr 67, Szczecin.

Garczarczyk J. (red.) (2009), Rynek ustug finansowych a koniunktura gospodarcza, CeDeWu, Warszawa.

Giełda a rozwój (2008), Fundacja FOR, PricewaterhouseCoopers, Stowarzyszenie Emitentów Giełdowych, Warszawa.

Hassapis C., Kalyvitis S. (2001), Economic Growth And Market Valuation Of Capital, "SSRN ELECTRONIC JOURNAL", http://dx.doi.org/10.2139/ssrn.187828.

Hassapis C., Kalyvitis S. (2002), Investigating the Links between Growth and Stock Price Changes with Empirical Evidence from the $G 7$ Economies, "The Quarterly Review of Economics and Finance", vol. 42, issue 3.

Jin D., Boubakari A. (2010), The Role of Stock Market Development in Economic Growth: Evidence from Some Euronext Countries, "International Journal of Financial Research", vol. 1, no. 1.

Kasprzak-Czelej A. (2012), Giełdowy rynek akcji a gospodarka. Ujęcie funkcyjne, Difin, Warszawa.

Levine R., Loayza N., Beck T. (2000), Financial Intermediation and Growth: Causality and Causes, "Journal of Monetary Economics", vol. 46 (1).

Michorowski M. (2013), Konkurencyjność polskiego rynku giełdowego na tle giełd papierów wartościowych krajów członkowskich Unii Europejskiej, „Zeszyty Naukowe Uniwersytetu Szczecińskiego", nr 768, Finanse, rynki finansowe, ubezpieczenia, nr 63, Szczecin.

Schwert W. (1990), Stock returns and real activity: a century of evidence, "Journal of Finance", vol. 45.

Stąpała J. (2012), Tempo zmian koniunktury gospodarczej i giełdowej w Polsce w latach 1998-2011, „Studia Ekonomiczne. Zeszyty Naukowe Uniwersytetu Ekonomicznego w Katowicach”, nr 3 (LXXIV).

Widz E. (2010), Korelacja między zmiennościa wybranych indeksów akcji giełd europejskich i amerykańskich, „Zeszyty Naukowe Uniwersytetu Szczecińskiego”, nr 616, Finanse, rynki finansowe, ubezpieczenia, $\mathrm{nr}$ 29, Szczecin.

Wyżnikiewicz B. (2007), Związi między koniunktura giełdowa a koniunktura makroekonomicz$n q w$ Polsce, Konferencja Wall Street, www.sii.org.pl/static/img/_186103547.pdf (dostep: 26.06.2015).

Wyżnikiewicz B., Fundowicz J., Peterlik M., Łapiński K., Dudek Ł. (2005), Silna giełda siła gospodarki, Instytut Badań nad Gospodarką Rynkową, Warszawa. 


\title{
Ewa Widz
}

\section{THE RELATIONSHIP BETWEEN THE MARKET INDICES FLUCTUATIONS AND FLUCTUATIONS OF THE ECONOMIC SITUATION IN POLAND}

\begin{abstract}
The paper examines the relationship between the stock market situation, represented by the rates of returns of the main market indices on Warsaw Stock Exchange, and the economic situation in Poland, measured by dynamics of GDP. The aim of the study is to answer the question if fluctuations of stock market indices precede GDP fluctuations. The analysis is based on the quarterly dynamics of change in the period of 2003-2014. The research shows that the correlation between dynamics of the main market indices on WSE and the GDP dynamics in Poland is positive, but moderate. Generally, the market indices fluctuations precede GDP fluctuations. However, the analysis of high rates of GDP changes proves their stronger correlation with simultaneous fluctuations of indices. In addition, it has been noticed that the analysed correlation in Poland systematically declines.
\end{abstract}

Keywords: stock market situation, Warsaw Stock Exchange indices, dynamics of GDP in Poland. 